\title{
Sediments and herbivory as sensitive indicators of coral reef degradation
}

\author{
Christopher H.R. Goatlev ${ }^{1,2}, \underline{\text { Roberta M. Bonaldo }}^{1,2,3}$, Rebecca J. Fox $^{1,2,4,5}$ and David R. Bellwood $^{1,2}$
}

\begin{abstract}
Around the world, the decreasing health of coral reef ecosystems has highlighted the need to better understand the processes of reef degradation. The development of more sensitive tools, which complement traditional methods of monitoring coral reefs, may reveal earlier signs of degradation and provide an opportunity for pre-emptive responses. We identify new, sensitive metrics of ecosystem processes and benthic composition that allow us to quantify subtle, yet destabilizing, changes in the ecosystem state of an inshore coral reef on the Great Barrier Reef. Following severe climatic disturbances over the period 2011-2012, the herbivorous reef fish community of the reef did not change in terms of biomass or functional groups present. However, fish-based ecosystem processes showed marked changes, with grazing by herbivorous fishes declining by over $90 \%$. On the benthos, algal turf lengths in the epilithic algal matrix increased more than $50 \%$ while benthic sediment loads increased 37 -fold. The profound changes in processes, despite no visible change in ecosystem state, i.e., no shift to macroalgal dominance, suggest that although the reef has not undergone a visible regime-shift, the ecosystem is highly unstable, and may sit on an ecological knife-edge. Sensitive, process-based metrics of ecosystem state, such as grazing or browsing rates thus appear to be effective in detecting subtle signs of degradation and may be critical in identifying ecosystems at risk for the future.
\end{abstract}

Key Words: disturbances; ecosystem state; herbivory; management; monitoring; processes; resilience; sediment; thresholds

\section{INTRODUCTION}

The health of coral reefs is declining worldwide. The global average for coral cover on reefs may be as low as $26 \%$ (Goatley and Bellwood 2011), and even the Great Barrier Reef (GBR), with world-leading management, has probably lost over half of its corals in the last three decades (Bellwood et al. 2004, De'ath et al. 2012). Comparable declines in the health of a human would leave medical practitioners searching for signs and symptoms to determine the cause of the illness. Coral reefs, regrettably, cannot tell us what is wrong, which leaves ecologists searching for visible signs of degradation.

Unfortunately, until recently our understanding of coral reef degradation has been limited, and therefore the signs ecologists have traditionally used are relatively crude. Declines in coral cover and/or increasing macroalgal cover are the most common metrics of reef health, yet they are also end-points of degradation. Once these signs are apparent, the reef has degraded and the damage is done. Rather than allowing a diagnosis, reporting these signs is perhaps more analogous to providing a coroner's report. However, with recent advances in our understanding of the mechanisms of coral reef degradation (Graham et al. 2006, 2013, Hughes et al. 2013) we now have the potential to determine more precise signs, and may be able to diagnose coral reef degradation before it is manifest by the widespread loss of taxa (e.g., McClanahan et al. 2011, Bruno et al. 2014).

In addition to standard measures of benthic cover on coral reefs (coral and macroalgal cover) changes in ecosystem state on coral reefs are often assessed using coral reef fish abundance. Fishes play critical roles in the functional ecology of coral reefs and herbivorous reef fishes are particularly important in preventing and reversing the development of stands of macroalgae (Bellwood et al. 2004, Hughes et al. 2007). Monitoring the diversity, abundances, and/or relative sizes of herbivorous fishes that perform these important functions is fast becoming a key step in the evaluation of coral reef resilience (Bruggemann et al. 1996, Bonaldo and Bellwood 2008, Lokrantz et al. 2008, Nyström et al. 2008, Green and Bellwood 2009). The numbers of organisms present in an ecosystem, however, do not always relate to the functions they perform, even within functional groups (Nyström 2006, Nyström et al. 2008, Graham et al. 2013, Mouillot et al. 2014). As such, more recent advances have advocated the use of multidimensional niche or trait-based metrics of fish or coral communities as measures of ecosystem state (Villéger et al. 2011, Darling et al. 2012, 2013, Mouillot et al. 2013). However, regardless of the complexity of the metrics used, most studies still rely on measuring the abundance and/or diversity of organisms.

Rather than counting organisms and predicting their likely impact in an ecosystem, it may be more beneficial to quantify their realized ecosystem functions, i.e., examining the realized rather than the potential niches. Quantifying processes in this manner may provide earlier signs of degradation, as organisms need not be lost. It also provides a way to measure the impact of species that are difficult to count through observer avoidance, e.g., browsing herbivores (Fox and Bellwood 2008, Dickens et al. 2011), and offers insights into variation in processes that may not be apparent from counts alone (Hoey and Bellwood 2010, Bennett and Bellwood 2011, Loffler et al. 2015a). Given that these changes in processes may depend on behavioral responses to environmental conditions (e.g., Bellwood and Fulton 2008, Goatley and Bellwood 2013), rather than abundance, they are likely to be both sensitive and capable of rapid responses. Quantifying ecological processes or the factors that affect them may therefore provide the earliest signs of degradation, perhaps even allowing the development of predictive tools.

\footnotetext{
${ }^{1}$ College of Marine and Environmental Sciences, James Cook University, ${ }^{2}$ Australian Research Council Centre of Excellence for Coral Reef Studies, ${ }^{3}$ Departamento de Ecologia Instituto de Biociências, Universidade de São Paulo, ${ }^{4}$ Division of Evolution, Ecology and Genetics, Australian National University, ${ }^{5}$ School of Life Sciences, University of Technology Sydney
} 
Table 1. List of severe climatic events affecting Pioneer Bay, Orpheus Island between February 2011 and August 2012.

\begin{tabular}{|c|c|c|}
\hline Date & Event & Description of event \\
\hline 3 February 2011 & Cyclone & $\begin{array}{l}\text { Severe Tropical Cyclone Yasi. Winds in excess of } 110 \mathrm{~km} \mathrm{~h}^{-1} \text { (anemometer } \\
\text { destroyed), } 2.5-4 \mathrm{~m} \text { storm surge across Pioneer Bay, and } 0.5-3 \mathrm{~m} \text { depth of debris } \\
\text { deposited on shore, } \\
2 \mathrm{~m} \text { beach erosion. }\end{array}$ \\
\hline Feb.-March 2011 & Turbidity & Following Cyclone Yasi underwater visibility remained $<0.5 \mathrm{~m}$ for 2 months. \\
\hline March 2011 & Flooding & $\begin{array}{l}\text { Excessive rainfall resulting in the release of remaining debris from Cyclone Yasi } \\
\text { (e.g., 2-m high piles of sugar cane debris on beach). }\end{array}$ \\
\hline 4 February 2012 & Flooding & $\begin{array}{l}\text { Tropical Cyclone Jasmine resulted in high rainfall, leading to high turbidity and } \\
\text { low salinity. }\end{array}$ \\
\hline 20 March 2012 & Tornado & Tornado in Pioneer Bay resulting in high winds, waves, and turbidity. \\
\hline August 2012 & Temperature & Unusually low winter temperature of $17^{\circ} \mathrm{C}$. \\
\hline
\end{tabular}

Recent theoretical work suggests that changes in the nature of variance around equilibrium ecosystem states, e.g., increasing amplitude, skewness, or autocorrelation, can precede regime shifts, and thus act as predictive tools (Guttal and Jayaprakash 2008, Dakos et al. 2008, Scheffer et al. 2009, Benedetti-Cecchi et al. 2015). Early detection or even pre-emptive management is therefore dependent on the sensitivity of the metrics used, with the literature often calling for sensitive metrics with which to test and apply theoretical models (Scheffer et al. 2001, van Nes and Scheffer 2005, Biggs et al. 2009). Such sensitive metrics are largely lacking on coral reefs (but see Chong-Seng et al. 2014, Bennett et al. 2015).

We therefore aimed to assess novel process-based and benthic metrics by taking advantage of data from before and after a series of extreme climatic disturbances at Orpheus Island on the GBR. The inner shelf location of Orpheus Island makes it more prone to sediment and freshwater inputs, and the most damaging phases of tropical cyclones (DeVantier et al. 1997, Walther et al. 2013). Despite these potential stressors, Pioneer Bay has previously been demonstrated to be a resilient ecosystem (Bellwood et al. 2006a, Hughes et al. 2007). Between 2011 and 2012 this resilience was tested as Orpheus Island was subjected to several unusually severe climatic events (Table 1), including direct and indirect impacts of Severe Tropical Cyclone Yasi (Perry et al. 2014). By repeating measures of ecosystem state before and after the climatic events we could compare traditional and process-based metrics of ecosystem condition. Specifically, our aims were the following: (1) to assess how disturbances affect the ecosystem state and ecological processes involved in both the resilience and recovery potential of coral reefs, and (2) to test whether changes in processes or benthic metrics may provide earlier indications of degradation than the currently used abundance-based metrics, e.g., fish, coral, or macroalgal cover.

\section{METHODS}

\section{Study site}

All aspects of this study were conducted in austral summers (December-April) between 2005 and 2013 within Pioneer Bay on the leeward (west) coast of Orpheus Island on the inner shelf of the GBR, Australia. To test the sensitivity of process-based and benthic metrics in detecting impacts of disturbances, data for each aspect of this study were collected before and after a series of climatic disturbances that affected Pioneer Bay between 2011 and 2012 (Table 1).

\section{Standard metrics}

Fish abundance

Fish censuses were conducted on the reef crest in Pioneer Bay initially in December 2005, and subsequently in November 2012 and October 2013. To minimize any effects of the divers on the fish present (e.g., Dickens et al. 2011) we used distance-calibrated 5-minute timed swims by two divers on SCUBA (following Fox and Bellwood 2007). The first diver counted nominally herbivorous fishes belonging to the families Acanthuridae, Ephippidae, Kyphosidae, Pomacanthidae, Pomacentridae, Labridae (tribe: Scarini), and Siganidae over $10 \mathrm{~cm}$ (total length) in a 5-m wide transect, estimating size within 5-cm categories. The second diver counted $5-10 \mathrm{~cm}$ long individuals in a $1-\mathrm{m}$ wide transect (widths were calibrated before each swim). In each year (2005, 2012, and 2013), 12 replicate, nonoverlapping swims were made across the entire bay. The census data were then used to calculate the biomass of each species using published length weight regressions (Green and Bellwood 2009). Change in biomass over time was then assessed using a one-way analysis of variance (ANOVA). To visualize any shifts in the taxonomic composition of the herbivorous fish community over time, the biomass-standardized census data were used to create a multidimensional scaling (MDS) plot. A subsequent one-way analysis of similarity (ANOSIM) with Year as a factor was then used to test for any statistically significant groupings among years.

To explore any changes in the biomass of specific functional groups of herbivorous fishes over time, each species was categorized into one of seven functional groups (Table A1.1; following Green and Bellwood 2009, Brandl and Bellwood 2013, 2014). The biomass per functional group was then used to produce a second MDS and ANOSIM. All multidimensional analyses were conducted in PRIMER 6.0 PERMANOVA+ using a BrayCurtis similarity matrix of square-root transformed biomass data.

\section{Process-based metrics}

In this study we focus on two separate categories of herbivory: grazing and browsing. We define grazing as removal of material from the epilithic algal matrix (EAM; a composite of filamentous algal turfs, detritus, sediment, and infauna; Wilson et al. 2003), whereas browsing represents the removal of fronds or thalli of erect macroalgae (Hoey and Bellwood 2010, Streit et al. 2015). 


\section{Grazing}

Grazing pressure was assessed in October 2005, then in November 2012 and October 2013 using static underwater video cameras to record reef fish herbivory on reef crest EAMs (following Fox and Bellwood 2007). One- $\mathrm{m}^{2}$ PVC quadrats were haphazardly placed on low-complexity horizontal EAMs. Video cameras were then placed to include the quadrat in the field of view, and set recording. After approximately 10 seconds the PVC quadrat was removed and the site left undisturbed for approximately five hours. Videos were subsampled, counting all bites made on the benthos during the second 15 minutes of each hour (to reduce the effect of the diver during deployment; Dickens et al. 2011), ensuring at least four 15-minute sections were viewed. Fish were identified to species and their size estimated using the quadrat as a calibration. The mass of individual fishes was estimated using published length weight regressions (Green and Bellwood 2009) and mass standardized bites were calculated by multiplying the mass of the fish $(\mathrm{kg})$ by the number of bites taken following (Bellwood et al. 2006a). This helps correct for any effect of the size of the fishes taking bites. Mass standardized bite data were compared using a two-way ANOVA. Residuals were assessed and data were subsequently square-root transformed to meet assumptions of the test.

\section{Algal turf bioassays}

To assess any changes in the impacts of fish feeding on the EAMs in Pioneer Bay, turf algal assays were conducted in January 2009, then repeated in November of 2012 and October 2013. Assays were deployed (following Bonaldo and Bellwood 2011) by collecting 20-30 rocks with attached EAMs from two sites on the reef flat, where limited herbivory results in increased algal lengths (Fox and Bellwood 2007, Bonaldo and Bellwood 2011). These rocks were subject to one of two treatments: transplant or control. Transplanted rocks $(n=5-10$ replicates per site in each period) were labelled, placed in sealed containers to minimize dislodgement of sediment, detritus, or infauna and carefully moved to their deployment sites on the crest adjacent to their collection site, in the zone of highest grazing pressure (as per Fox and Bellwood 2007). Control rocks were moved in the same manner but replaced at their collection site on the reef flat, to account for any effects of dislodging sediment, detritus, or infauna in transport. This allowed comparisons to be made of the realized impacts of grazers on identical surfaces between the flat and crest. Algal turf height was measured four days after deployment, using calibrated forceps or the depth probe of vernier calipers (following Bonaldo and Bellwood 2011; $\mathrm{n}=5-10$ replicates per rock). Changes in the responses of algal turf length between treatments and controls and between years were initially compared using a three-way ANOVA of $\log _{10}(n+1)$ transformed data. Where sites had no effect, data were pooled and a two-way ANOVA was conducted.

\section{Macroalgal bioassays}

To assess the ability of Pioneer Bay to recover following a potential shift to macroalgal dominance, we conducted macroalgal transplants during an undergraduate field course each April from 1996 to 2013. Each year, two 24-hour deployments were conducted, separated by 48 to 72 hours. For each deployment, bioassays were created by collecting approximately 20 replicate rocks with attached Sargassum thalli (10-20 thalli per rock, each $0.5-1 \mathrm{~m}$ long) from areas of low browsing intensity (usually the adjacent reef flat). Half of the rocks were transplanted to the reef crest in Pioneer Bay and left undisturbed for 24 hours. The remaining rocks were treated as controls, and replaced on the reef flat, where Sargassum is abundant. Rocks were deployed at approximately 1-m intervals along a 10-m line laid on the benthos running at a consistent depth and perpendicular to shore. The controls were deployed to account for any impact of transplanting the bioassays, e.g., handling loss or increased herbivory through dislodging sediment or epiphytes. All bioassays were collected after 24 hours. Time limitations on undergraduate field courses combined with extreme responses meant that changes to the Sargassum were designated into one of two categories: "largely removed" representing complete removal of fronds and most thalli; or "largely intact" representing no visible change to the deployed bioassay over the study period (Fig. A1.1). The second annual deployment was conducted after two to three days, by repeating the entire experimental procedure.

\section{Benthic metrics}

\section{Algal turf length}

Lengths of algal turfs in the EAM were measured in January 2009 (Bonaldo and Bellwood 2011) and repeated in November 2012 and October 2013. A minimum of 20 measurements in each habitat (crest and flat) were taken at two sites within Pioneer Bay, from algal turfs on flat, low complexity reef matrix, away from damselfish territories. Data were initially compared using a threeway analysis of variance (ANOVA). Where site was found to have no effect, data were pooled and two-way analyses conducted. All data were square-root transformed to meet assumptions of the test.

\section{Benthic sediment load}

Immediately following the measurement of algal turf lengths, in 2009 and 2013, benthic particulate matter (sediments and particulate organic material) was collected from the same locations. Five replicate $58 \mathrm{~cm}^{2}$ ring enclosures were haphazardly positioned on flat EAMs and particulates collected using an electronic sediment vacuum (Purcell 1996). Particulate loads were determined from dried samples, then the organic fraction was removed by bleaching the samples in sodium hypochlorite $(10 \%)$ for three days and repeating this process three times. After three fresh water rinses, to remove salts and residues, the sample was dried and weighed to determine the sediment load (inorganic fraction; Bonaldo and Bellwood 2011). Changes in particulate and sediment loads were assessed using a two-way ANOVA of square-root transformed data, with material treated as a repeated measure to account for the nonindependence associated with successive weighing of the same samples. To better quantify the nature of the particulates further sample processing was conducted on the samples from 2013. The bleached samples were dry sieved into fractions using a sieve stack $(1000,500,250,125$ and $63 \mu \mathrm{m}$ grades) and the fractions weighed. Carbonates were then removed by dissolution in $5 \%$ hydrochloric acid $(\mathrm{HCl})$ until any visible reactions ceased (Brown-Saracino et al. 2007, Gordon et al. 2016). The remaining sediments were rinsed, dried, weighed, and sieved (as above) to determine the properties of the insoluble fraction of the sample (siliceous sediments). 


\section{RESULTS}

\section{Standard metrics}

\section{Fish abundance}

No change in the biomass of herbivorous reef fishes was observed between 2005, 2012, and 2013 (Fig. 1). Likewise, the taxonomic composition of the herbivorous fish assemblage did not appear to change between the years (ANOSIM, sites pooled; Global $R$ $=0.4$; no pairwise tests $>0.5$; Fig. A1.2; Table A1.2). When assessing any changes in the functional group composition of the herbivorous fish assemblage, no difference was apparent between the years (ANOSIM, sites pooled; Global $R=0.2$; no pairwise tests > 0.5; Fig. A1.3).

Fig. 1. The biomass of herbivorous fishes observed in Pioneer Bay, Orpheus Island at three time periods since 2005. No significant differences in biomass were recorded over time. Six 5-minute timed swims (distance calibrated) were conducted in two sites in Pioneer Bay at each time. Sites are pooled because difference was nonsignificant. Symbol denotes disturbance events including Severe Tropical Cyclone Yasi in 2011. Data are presented as means \pm standard error.

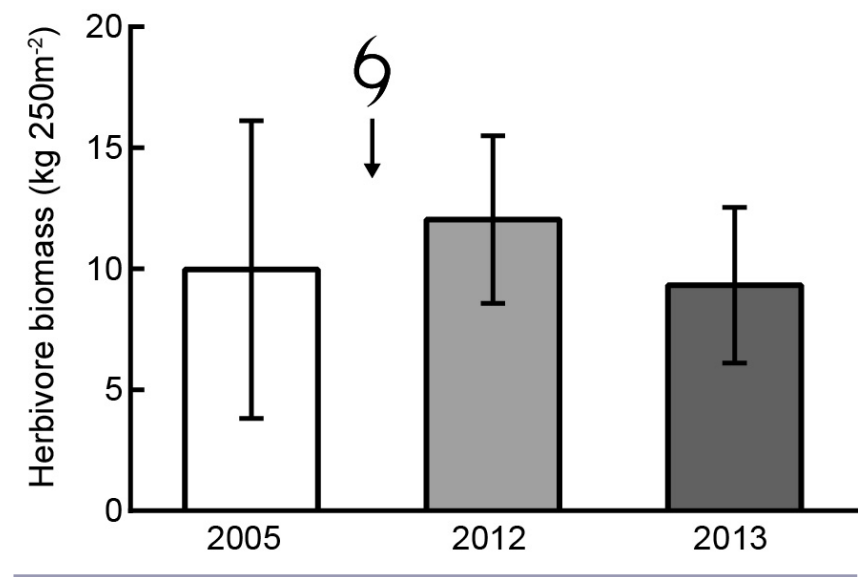

\section{Process-based metrics}

\section{Grazing}

Although the abundance and functional group composition of the herbivorous fish assemblage did not change after the disturbances, the feeding behavior of grazing herbivores showed dramatic shifts. In 2012 the grazing rate of parrotfishes on low complexity horizontal EAMs had almost ceased, and was only $2 \%$ of the rates observed in 2005 . Rabbitfish feeding had likewise reduced by $92 \%$ between 2005 and 2012. Neither group showed any increases in their grazing intensity by 2013 (Fig. 2a; ANOVA interaction, $F_{2,67}=8.9, P<0.001$; Table A1.3).

Algal turf bioassays

In 2009, turf algal assays transplanted to the reef crest were grazed to ambient levels ( $54 \%$ reduction) in four days. On repeating the experiment in 2012 and 2013 there was no sign of reduction (Fig. 2b). Indeed, in 2013 the length of algal turfs increased by $16 \%$. (ANOVA interaction, $F_{2,74}=21.5, P<0.0001$; Table A1.4).
Macroalgal bioassays

In April 2011 the Sargassum on the first annual macroalgal bioassay deployment were not removed (all bioassays were categorized as "largely intact"). This marked the first sign of changing processes affecting the recovery potential of Pioneer Bay. Each year since 1996, all macroalgal bioassays had been grazed down to the attachment within $24 \mathrm{~h}$ (Fig. A1.1). Since 2011, the first deployment (of the two annual trials) has consistently shown limited removal, with at least $60 \%$ of assays categorized as "largely intact" (Fig. A1.1). The second deployments, conducted 2-3 days later have consistently been removed with all assays in the "largely removed" category.

Fig. 2. (a) The grazing rate of parrotfish (Labridae; Scarini) and rabbitfish (Siganidae) on epilithic algal matrices (EAMs), observed in 2005, 2012, and 2013 (only these taxa were observed feeding). ${ }^{\dagger}$ Note that initial feeding observations were made in 2005 rather than 2009. (b) The capacity for grazers to control the growth of algal turfs was assessed by comparing lengths of control assays on the reef flat with transplanted assays moved to the reef crest for three days. No changes were observed in 2012 and 2013. Symbols denote disturbance events including Severe Tropical Cyclone Yasi in 2011. Data are presented as means \pm standard error.
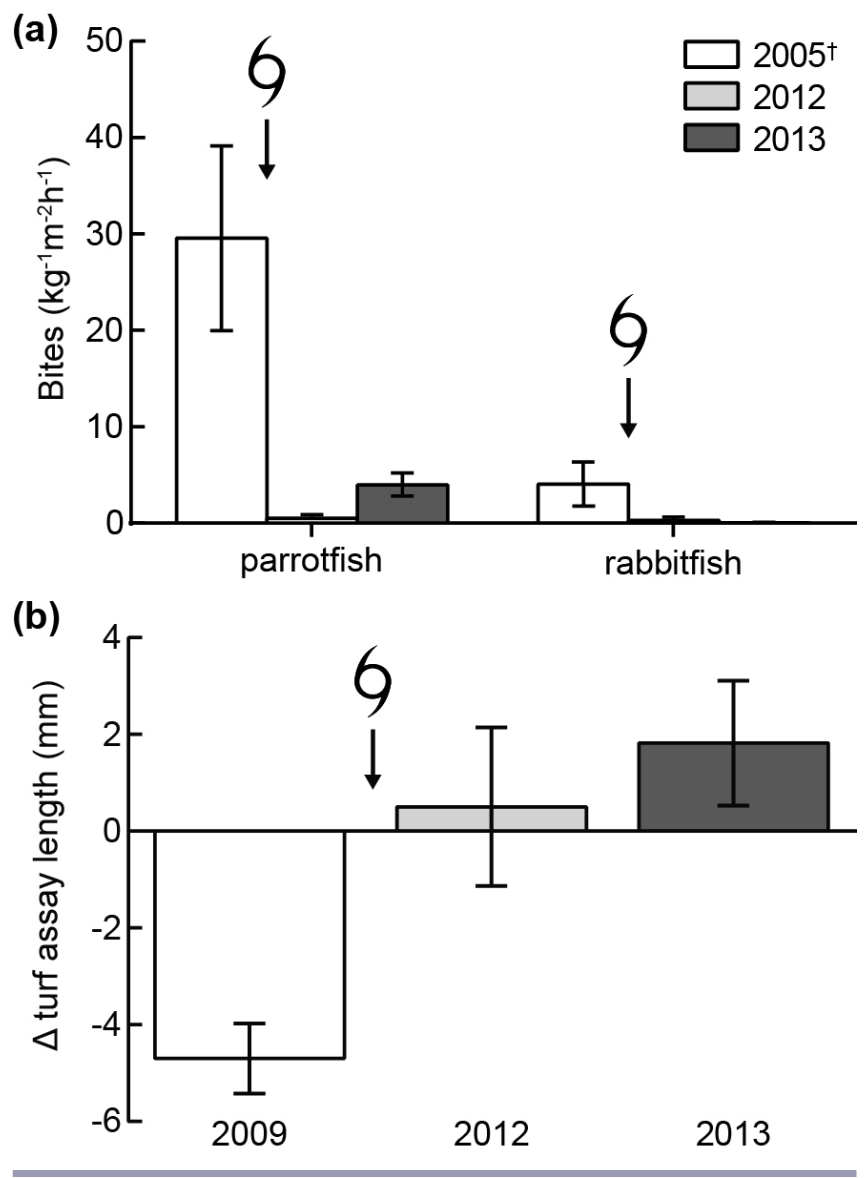


\section{Benthic metrics}

\section{Algal turf length}

The length of algal turfs in the EAM increased between 2009 and 2012, and remained high in 2013 (ANOVA $F_{2,7.2}=14.8, P>$ 0.0001; Fig. 3a). At all times the reef flat had longer algal turfs compared to the crest (ANOVA $F_{1,45.5}=93.3, P<0.0001$; no year $\times$ zone interaction), yet, increases in turf length between 2009 and 2012 were seen in both zones $(71 \%$ increase on the crest and $54 \%$ on the flat).

Fig. 3. (a) The length of algal turf filaments on the reef crest and flat of Pioneer Bay in 2009, 2012, and 2013, respectively. Cyclone Yasi was in 2011. Letters in bars indicate groupings derived from a Tukey's HSD post hoc test. (b) The epilithic algal matrices (EAM) sediment loads in 2009 and 2013 (see particle sizes and composition in Fig. A1.4). Symbols denote disturbance events including Severe Tropical Cyclone Yasi in 2011. Data are presented as means \pm standard error.
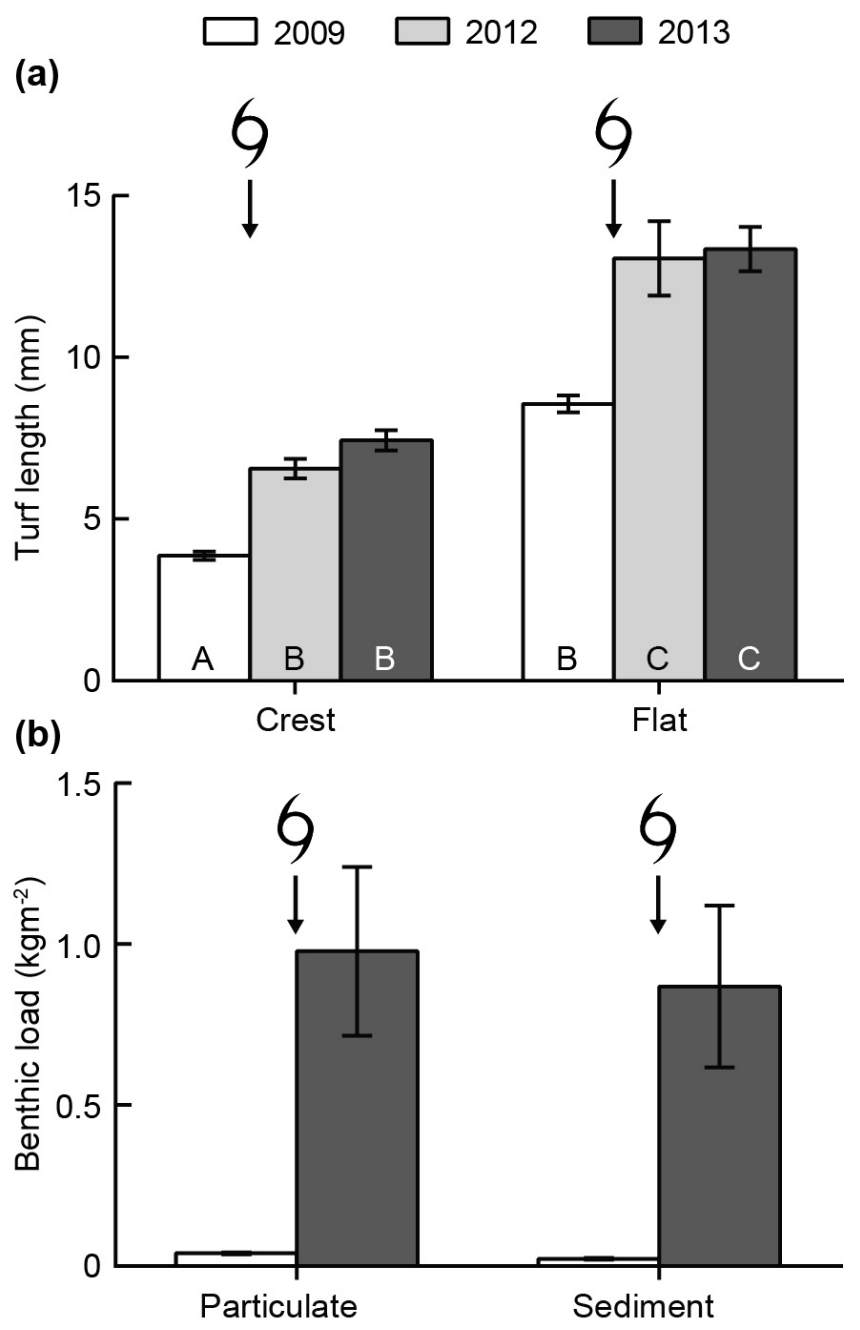

\section{Benthic sediment load}

Increases in benthic particulate material and sediments were also observed between 2009 and 2013. Particulate loads in the EAM increased 24-fold between 2009 and 2013 (Fig. 3b). Even more striking was the 37 -fold increase in benthic sediment load (from 23 to $868 \mathrm{gm}^{-2}$; ANOVA interaction, $F_{1,18}=4.5, P<0.05$; Table A1.5). Although particle size analysis was not conducted in 2009 , benthic sediments in 2013 contained an unusually high proportion of fine particles (on average $49.4 \pm 6.3 \%$ [mean \pm standard error] of sediments in each sample were $<63 \mu \mathrm{m}$ ), which were predominantly siliceous. On average $34.6 \pm 4.2 \%$ of sediments in each sample were siliceous, all of which fell into the $<63 \mu \mathrm{m}$ category. Siliceous sediments on average accounted for 70.9 $\pm 2.2 \%$ of the sediments in this grain size category (Fig. A1.4).

\section{DISCUSSION}

A series of severe climatic disturbances, including one of the largest cyclones ever recorded in this region (Perry et al. 2014), did not change the fish community of Orpheus Island, nor did they induce a phase-shift to macroalgal dominance. However, unlike traditional measures of ecosystem state, the metrics used in the present study revealed distinct signs of potential degradation. These signs highlighted critical changes in the ecosystem function of Pioneer Bay. Although the herbivorous fish assemblage had not changed since 2005 in terms of biomass or functional composition, by 2012 changes in the feeding behavior of the herbivores resulted in reductions in grazing and browsing; both vital ecosystem process. Grazing of algal turfs by reef fishes almost ceased on horizontal EAMs and, as a result, longer turfs transplanted to the reef crest did not show the rapid reductions observed in previous years. Browsing of macroalgae by fishes also appeared to be compromised in Pioneer Bay, with unusual changes in the extent of removal of transplanted macroalgae. These sensitive assays revealed both changes in crucial ecological functions in Pioneer Bay, and the possible mechanistic basis of coral reef degradation on coastal reefs.

\section{Progressive changes in coral reef degradation}

Understanding the progression of ecological changes associated with coral reef degradation is critical to monitoring and managing coral reefs for the future. By identifying the processes that are most sensitive to change we can use them as cues for early or even pre-emptive management responses. Although the increases in benthic sediment load and algal turf length were recorded simultaneously, it seems likely that the sediment loads changed first, driving changes in both herbivory (Bellwood and Fulton 2008, Goatley and Bellwood 2012, Clausing et al. 2014, Gordon et al. 2016) and algal turfs (cf. Goatley and Bellwood 2013). Suspended sediment from flooding associated with Cyclone Yasi reduced visibility in Pioneer Bay for at least two months in early 2011 and is the most likely source of the fine, highly siliceous sediments found on the benthos in 2013 (cf. Bainbridge et al. 2012, Kroon et al. 2012). Increased benthic sediment loads are associated with algal turf growth (Goatley and Bellwood 2013), and although the cause of this growth is uncertain (it may be associated with increased nutrients), the most likely driver appears to be the suppression of herbivory by coral reef fishes (Bellwood and Fulton 2008, Cheal et al. 2013, Goatley and Bellwood 2013, Gordon et al. 2016).

Our measures of ecological processes offer support for this scenario. In 2009, long algal turfs transplanted to the reef crest were rapidly grazed by resident fishes until they were at a similar length to the surrounding algal turfs (Bonaldo and Bellwood 
2011). However, in 2012 and 2013 algal turfs had increased in length on the reef crest, and when longer turfs were transplanted to the crest, they showed no reductions in length over time. This was particularly surprising because the herbivorous fish assemblage remained unchanged in terms of both biomass and functional composition. In 2005 the intensity of grazing by fishes was sufficient to remove turf algae from all horizontal EAMs in Pioneer Bay more than once a month (Fox and Bellwood 2007), yet by 2012 we found that this feeding behavior had almost ceased (92-98\% reductions). There are three potential causes of this reduction: (1) increased food quality, (2) increased food availability leading to satiation of herbivores, or (3) decreased food palatability. The first, an increase in the nutritional quality of the EAM, leading to reduced necessity to feed (e.g., Choat and Clements 1993, Choat et al. 2004, Clements et al. 2009), seems highly unlikely because the amount of inorganic material (sediment) in the EAM had increased 37-fold (cf. Choat 1991). Similarly, satiation through increased availability of algae seems unlikely. Horizontal EAMs on the reef crest are the preferred feeding surface for grazing herbivores (Bellwood and Choat 1990, Fox and Bellwood 2007, Welsh and Bellwood 2012) and the area available for feeding in Pioneer Bay is unlikely to have changed because the only major coral losses in Pioneer Bay occurred earlier, in 1998 and 2001 (Bellwood et al. 2006b), leaving large areas of the crest open for grazing. Rather, the herbivorous fishes appear to have changed their feeding rates and/or preferences. Qualitative observations of grazing by herbivores and parrotfish bite scar locations suggest that herbivorous fishes post-2012 have shifted to grazing on steep or vertically oriented surfaces, which traditionally were nonpreferred (Bellwood and Choat 1990, Babcock and Davies 1991, Trapon et al. 2013, Brandl and Bellwood 2014), but now offer an alternative, and perhaps the only remaining low-sediment feeding surfaces. Future studies should be conducted to quantify this impact because grazing location may prove to be another useful metric of ecosystem change.

Benthic sediment load appears to be a highly sensitive indicator and driver of ecosystem change on coral reefs. Early detection of changes in sediment loads may also indicate forthcoming changes in herbivory and other processes, e.g., coral recruitment (Birrell et al. 2005). Changing sediment loads may therefore prove useful as a predictive tool for ecosystem transitions (Scheffer et al. 2009, Benedetti-Cecchi et al. 2015) or as an early indication of a shift to an alternative stable state. However, the value of this potential metric is limited because direct quantification of benthic sediments is difficult and time consuming (Purcell 1996). Sediments must be collected using specialized equipment (Purcell 1996, Kramer et al. 2013) and processed over a period of weeks prior to weighing (Gordon et al. 2016). Because very slight variations in sediment load have instantaneous and considerable impacts on herbivory (Bellwood and Fulton 2008, Goatley and Bellwood 2012, 2013, Clausing et al. 2014), the most practical tool to measure changes in effective sediment load may therefore be rates of herbivory.

\section{Subtle signs of ecosystem degradation: grazing and algal turfs} Grazing herbivores maintain short productive algal turfs (SPATs) and prevent potential succession from algal turfs to larger macroalgae (Hixon and Brostoff 1996, Hughes et al. 2007,
Burkepile and Hay 2010) or long sediment-laden algal turfs (LSATs; Bellwood and Fulton 2008, Goatley and Bellwood 2012, 2013). These productive EAMs also provide habitats and settlement surfaces for coral reef invertebrates (Birrell et al. 2008, Diaz-Pulido et al. 2010, Kramer et al. 2012, 2013). Any reductions in grazing can lead to the development of long, unpalatable algal turfs (Goatley and Bellwood 2013). Although the absolute length increases we observed may seem small (2.7-4.6 mm increases on the crest and flat), EAMs are often the most abundant benthic cover on coral reefs (Vroom 2011, Goatley and Bellwood 2011, Bruno et al. 2014) and are often highly stable (Hay 1981, Airoldi and Virgilio 1998, Goatley and Bellwood 2013). Even small changes in their composition can thus have widespread impacts on ecosystem function (Goatley and Bellwood 2012, 2013, Clausing et al. 2014). LSATs, as observed in Pioneer Bay, can stabilize, and even increase the deposition of benthic sediments (Eckman et al. 1989, Carpenter and Williams 1993), and inhibit coral settlement and survivorship (Birrell et al. 2005, 2008). Recovery to SPATs may be rapid where sediment loads are initially low (Bonaldo and Bellwood 2011), however, where sediment loads are high, LSATs can persist for a considerable time (Goatley and Bellwood 2013). This appears to be the case in Pioneer Bay, as long algal turfs did not change between 2012 and 2013 even in the presence of abundant grazers. This LSAT was present for at least a year and may in fact represent an alternate stable state. By monitoring grazing intensity, and its impact on turf length, we stand better chances of detecting these changes before they become chronic, and potentially permanent conditions on coral reefs.

Subtle signs of ecosystem degradation: browsers and macroalgae Although LSATs are likely to affect the resilience of Pioneer Bay, the limited removal of transplanted macroalgae suggests that the potential for recovery from macroalgal development has also been compromised. This is particularly worrying when combined with severely reduced grazing, which offers less control over the development of macroalgae. In most previous studies, individual thalli of Sargassum have been grazed within a day of deployment (this study, Mantyka and Bellwood 2007, Fox and Bellwood 2008, Cvitanovic and Bellwood 2009, Lefèvre and Bellwood 2011, Hoey and Bellwood 2011) and even large deployments of the macroalga, which simulate phase-shifts, have largely been removed in four to five days (Bellwood et al. 2006a, Hoey and Bellwood 2011). Although browsing has not faced the declines seen in grazing, even slight changes may affect the ability of the reef to prevent, and recover from, increasing macroalgal abundance (Hoey and Bellwood 2011, Graham et al. 2013). Similarly worrying is that the cause of reduced browsing is unclear (benthic sediments are unlikely to affect feeding on erect macroalgae); the browsers are still present and will remove algae given time (Loffler et al. 2015a, $b$ ), but their behavior is atypical and less responsive than in previous years. Combined with the lack of grazing to control development of macroalgae, compromised recovery potential could signal the possibility of bay-wide increases in macroalgal abundance, beyond the threshold where the local herbivore community is able to control expansion of macroalgae (cf. Hoey and Bellwood 2011). Our methods of estimating browsing have limitations because we only recorded data categorically ("largely removed" or "largely intact"). Nevertheless, even using these 
simple data we detected changes in ecological processes. When applied to monitoring programs, measuring the mass of algae lost (e.g., Hoey and Bellwood 2011) may prove to be an even more sensitive measure of changes in processes. Monitoring grazing and browsing may be the most effective method for evaluating the status of vulnerable locations. These methods move beyond counts because abundances do not relate to function (Bennett and Bellwood 2011, Vergés et al. 2012), they save time compared with collecting and processing sediments (Gordon et al. 2016), and measure processes with direct implications for ecosystem function. Whether herbivory acts as an early warning system or simply a first indicator of change, it may buy time for managers to act before alternate stable states are reinforced by feedbacks, or before key fish taxa and reef structure are lost (Graham et al. 2013).

One question remains. If Pioneer Bay is suffering from such extreme reductions in grazing and browsing, why have we not seen a shift to macroalgal dominance? Previous studies conducted in this location have revealed that reduced herbivory by fishes is the primary driver of phase-shifts to macroalgal dominance (Hughes et al. 2007), and that browsing reef fishes are critical for recovery following macroalgal development (Bellwood et al. 2006a, Fox and Bellwood 2008, Hoey and Bellwood 2011). The changes in grazing and browsing rates documented in this study seem to represent the ideal conditions for development of macroalgae in a system that has a history of this outcome. However, this has not occurred. The increased benthic sediment loads may be the explanation. Such increases have the potential to prevent the development of macroalgae (Airoldi and Virgilio 1998, Umar et al. 1998, Goatley and Bellwood 2013) and by suppressing herbivory (Bellwood and Fulton 2008, Clausing et al. 2014, Gordon et al. 2016) these sediments promote the development of long algal turfs (Goatley and Bellwood 2013). If this is the case, these LSATs now found on the reef crest in Pioneer Bay could represent a new and relatively stable state (Goatley and Bellwood 2013; cf. Norström et al. 2009). Alternatively, if benthic sediment loads change, e.g., in response to an ecosystem shock (Graham et al. 2013), Pioneer Bay may return to previous conditions, or shift to another stable state, such as macroalgal dominance.

The current stability of the ecosystem in Pioneer Bay remains unclear. However, the strong and rapid responses of processbased metrics (both grazing and browsing) to the otherwise unobserved changes in the benthic composition of Pioneer Bay, e.g., EAM sediment loads, indicate a critical shift in ecosystem function (Fig. 4). As benthic sediment loads appear to be the driver of these changes, the future may be dependent upon sediment dynamics. Reduction of sediment may result in increased grazing and recovery of the reef, however, if herbivores do not respond immediately, or have started to decline in abundance, there may be the potential for the development of macroalgae and feedbacks to reinforce this state (Hughes et al. 2007, Hoey and Bellwood 2011). If current rates of disturbances are maintained, the future of Pioneer Bay seems bleak (cf. Hughes et al. 2013; Table 1, Fig. 4).

Process-based metrics have proved capable of identifying subtle changes in an ecosystem that has been challenged by recent disturbances, and may represent a useful tool in developing
Fig. 4. (a) The standard representation of critical transitions in ecosystem states may lead to some confusion because the equilibrium ecosystem state is represented as a stable line (while the dashed line passes across an area where ecosystem transitions can occur). (b) "Equilibrium" states (dashed lines), however, may simply represent a time averaged artefact of our inability to monitor variability in processes in real time. For example, monitoring fish abundance or coral cover may have little relevance to the functions being performed by the groups and the resilience of the ecosystem being observed. Using more sensitive metrics, such as process-based monitoring, e.g., grazing rates, may provide instantaneous estimates of ecosystem state and allow detection of changes in the nature of this variance, e.g., increasing amplitude, skewness, or autocorrelation. In turn these changes ( $\Delta$ variance) may allow predictions of critical transitions through highlighting subtle shifts in function or through predictive models (cf. Dakos et al. 2008, Guttal and Jayaprakash 2008, Scheffer et al. 2009, Benedetti-Cecchi et al. 2015). Ecosystem transitions (arrows) are increasingly likely when fluctuations reach threshold states (horizontal yellow bars). Whether Pioneer Bay is at, or beyond a threshold state, is likely to depend upon the stability of the current benthic sediment loads. (a) redrawn from (Scheffer et al. 2009).
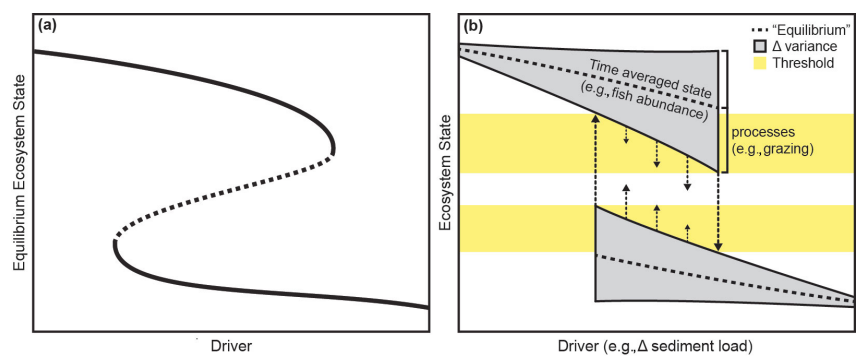

preventative management for the future. We recommend that process-based metrics including assessments of grazing rates and transplants of algal turf and macroalgal bioassays are implemented alongside current monitoring techniques. If time permits benthic metrics including sediment load and turf length could also be applied to provide useful indicators of the drivers of observed changes. These new methods may provide an opportunity to detect subtle signs of coral reef degradation and identify vulnerable locations prior to fundamental shifts in ecosystem state. In particular, process-based metrics can be applied quickly, easily, and at a low cost. Grazing rates appear highly responsive to environmental conditions and are best estimated from static underwater video deployments, which have recently been facilitated by the universal accessibility of affordable waterproof "action cameras" (Loffler et al. 2015a). Simultaneously, turf and macroalgal assays provide rapid assessments of the realized impacts of grazing and browsing herbivores; processes directly associated with coral reef resilience and recovery potential (Chong-Seng et al. 2014, Nash et al. 2015). If implemented alongside existing monitoring regimes, this new suite of metrics may, for the first time, allow us to pre-emptively manage vulnerable sites before corals and fish are lost. 


\section{CONCLUSION}

With this study, we have highlighted that, when used to complement traditional monitoring, subtle changes in ecosystem state including measures of ecosystem processes and EAM components can provide a more detailed understanding of the impacts of disturbances. Traditional monitoring provides a critical baseline of what species are present in an ecosystem to perform functions. Quantifying herbivory through bite rates and removal of algae from bioassays then provides an additional indication of the state of processes being performed by the species present, while benthic components from the EAM identify potential drivers of degradation (benthic sediment loads) and their subsequent impacts (algal turf length). Essentially, we can measure not only what is present in an ecosystem, but what it is doing, what effect this has on the ecosystem, and potentially, why. Given the dynamic and responsive nature of these subtle changes in ecosystem state, we may be able to apply them as tools to promote preventative management by early identification of ecosystems at risk.

Responses to this article can be read online at: http://www.ecologyandsociety.org/issues/responses. $\mathrm{php} / 8334$

\section{Acknowledgments:}

We wish to thank S. Brandl, S. Gordon, J.P. Krajewski, J. Welsh, and the staff of Orpheus Island Research Station for field and laboratory assistance and two anonymous reviewers for insightful comments. Research funded by the Australian Research Council (DRB), CAPES-Brazil (RMB) and the Great Barrier Reef Marine Park Authority (CHRG).

\section{LITERATURE CITED}

Airoldi, L., and M. Virgilio . 1998. Responses of turf-forming algae to spatial variations in the deposition of sediments. Marine Ecology Progress Series 165:271-282. http://dx.doi.org/10.3354/ meps 165271

Babcock, R., and P. Davies. 1991. Effects of sedimentation on settlement of Acropora millepora. Coral Reefs 9:205-208. http:// dx.doi.org/10.1007/BF00290423

Bainbridge, Z. T., E. Wolanski, J. G. Álvarez-Romero, S. E. Lewis, and J. E. Brodie. 2012. Fine sediment and nutrient dynamics related to particle size and floc formation in a Burdekin River flood plume, Australia. Marine Pollution Bulletin 65:236-248. http://dx.doi.org/10.1016/j.marpolbul.2012.01.043

Bellwood, D. R., and J. H. Choat. 1990. A functional analysis of grazing in parrotfishes (family Scaridae): the ecological implications. Environmental Biology of Fishes 28:189-214. http:// dx.doi.org/10.1007/BF00751035

Bellwood, D. R., and C. J. Fulton. 2008. Sediment-mediated suppression of herbivory on coral reefs: decreasing resilience to rising sea levels and climate change? Limnology and Oceanography 53:2695-2701. http://dx.doi.org/10.4319/lo.2008.53.6.2695
Bellwood, D. R., T. P. Hughes, C. Folke, and M. Nyström. 2004. Confronting the coral reef crisis. Nature 429:827-833. http://dx. doi.org/10.1038/nature02691

Bellwood, D. R., T. P. Hughes, and A. S. Hoey. 2006a. Sleeping functional group drives coral-reef recovery. Current Biology 16:2434-2349. http://dx.doi.org/10.1016/j.cub.2006.10.030

Bellwood, D. R., A. S. Hoey, J. L. Ackerman, and M. Depczynski. 2006b. Coral bleaching, reef fish community phase shifts and the resilience of coral reefs. Global Change Biology 12:1587-1594. http://dx.doi.org/10.1111/j.1365-2486.2006.01204.x

Benedetti-Cecchi, L., L. Tamburello, E. Maggi, and F. Bulleri. 2015. Experimental perturbations modify the performance of early warning indicators of regime shift. Current Biology 25:1867-1872. http://dx.doi.org/10.1016/j.cub.2015.05.035

Bennett, S., and D. R. Bellwood. 2011. Latitudinal variation in macroalgal consumption by fishes on the Great Barrier Reef. Marine Ecology Progress Series 426:241-252. http://dx.doi. org/10.3354/meps09016

Bennett, S., T. Wernberg, E. S. Harvey, J. Santana-Garcon, and B. J. Saunders. 2015. Tropical herbivores provide resilience to a climate-mediated phase shift on temperate reefs. Ecology Letters 18:714-723. http://dx.doi.org/10.1111/ele.12450

Biggs, R., S. R. Carpenter, and W. A. Brock. 2009. Turning back from the brink: detecting an impending regime shift in time to avert it. Proceedings of the National Academy of Sciences USA 106:826-831. http://dx.doi.org/10.1073/pnas.0811729106

Birrell, C. L., L. J. McCook, and B. L. Willis. 2005. Effects of algal turfs and sediment on coral settlement. Marine Pollution Bulletin 51:408-414. http://dx.doi.org/10.1016/j.marpolbul.2004.10.022

Birrell, C. L., L. J. McCook, B. L. Willis, and G. A. Diaz-Pulido. 2008. Effects of benthic algae on the replenishment of corals and the implications for the resilience of coral reefs. Oceanography and Marine Biology 46:25-63. http://dx.doi.org/10.1201/9781420065756. $\underline{\operatorname{ch} 2}$

Bonaldo, R. M., and D. R. Bellwood. 2008. Size-dependent variation in the functional role of the parrotfish Scarus rivulatus on the Great Barrier Reef, Australia. Marine Ecology Progress Series 360:237-244. http://dx.doi.org/10.3354/meps07413

Bonaldo, R. M., and D. R. Bellwood. 2011. Spatial variation in the effects of grazing on epilithic algal turfs on the Great Barrier Reef, Australia. Coral Reefs 30:381-390. http://dx.doi. org/10.1007/s00338-010-0704-4

Brandl, S. J., and D. R. Bellwood. 2013. Morphology, sociality, and ecology: can morphology predict pairing behavior in coral reef fishes? Coral Reefs 32:835-846. http://dx.doi.org/10.1007/ $\underline{\mathrm{s} 00338-013-1042-0}$

Brandl, S. J., and D. R. Bellwood. 2014. Individual-based analyses reveal limited functional overlap in a coral reef fish community. Journal of Animal Ecology 83:661-670. http://dx.doi. org/10.1111/1365-2656.12171

Brown-Saracino, J., P. Peckol, H. A. Curran, and M. L. Robbart. 2007. Spatial variation in sea urchins, fish predators, and bioerosion rates on coral reefs of Belize. Coral Reefs 26:71-78. http://dx.doi.org/10.1007/s00338-006-0159-9 
Bruggemann, J. H., A. M. van Kessel, J. M. van Rooij, and A. M. Breeman. 1996. Bioerosion and sediment ingestion by the Caribbean parrotfish Scarus vetula and Sparisoma viride: implications of fish size, feeding mode and habitat use. Marine Ecology Progress Series 134:59-71. http://dx.doi.org/10.3354/ meps134059

Bruno, J. F., W. F. Precht, P. S. Vroom, and R. B. Aronson. 2014. Coral reef baselines: how much macroalgae is natural? Marine Pollution Bulletin 80:24-29. http://dx.doi.org/10.1016/j. marpolbul.2014.01.010

Burkepile, D. E., and M. E. Hay. 2010. Impact of herbivore identity on algal succession and coral growth on a Caribbean reef. PLoS ONE 5:e8963. http://dx.doi.org/10.1371/journal.pone.0008963

Carpenter, R. C., and S. L. Williams. 1993. Effects of algal turf canopy height and microscale substratum topography on profiles of flow speed in a coral forereef environment. Limnology and Oceanography 38(3):687-694. http://dx.doi.org/10.4319/1o.1993.38.3.0687

Cheal, A. J., M. Emslie, M. A. MacNeil, I. Miller, and H. Sweatman. 2013. Spatial variation in the functional characteristics of herbivorous fish communities and the resilience of coral reefs. Ecological Applications 23(1):174-188. http://dx. doi.org/10.1890/11-2253.1

Choat, J. H. 1991. The biology of herbivorous fishes on coral reefs. Pages 120-155 in P. F. Sale, editor. The ecology of fishes on coral reefs. Academic Press, San Diego, California, USA. http:// dx.doi.org/10.1016/b978-0-08-092551-6.50011-8

Choat, J. H., and K. D. Clements. 1993. Daily feeding rates in herbivorous labroid fishes. Marine Biology 117:205-211. http:// dx.doi.org/10.1007/BF00345664

Choat, J. H., W. D. Robbins, and K. D. Clements. 2004. The trophic status of herbivorous fishes on coral reefs II. Food processing modes and trophodynamics. Marine Biology 145:445-454. http://dx.doi.org/10.1007/s00227-004-1341-7

Chong-Seng, K. M., K. L. Nash, D. R. Bellwood, and N. A. J. Graham. 2014. Macroalgal herbivory on recovering versus degrading coral reefs. Coral Reefs 33:409-419. http://dx.doi. org/10.1007/s00338-014-1134-5

Clausing, R. J., C. Annunziata, G. Baker, C. Lee, S. J. Bittick, and P. Fong. 2014. Effects of sediment depth on algal turf height are mediated by interactions with fish herbivory on a fringing reef. Marine Ecology Progress Series 517:121-129. http://dx.doi. org/10.3354/meps 11029

Clements, K. D., D. Raubenheimer, and J. H. Choat. 2009. Nutritional ecology of marine herbivorous fishes: ten years on. Functional Ecology 23:79-92. http://dx.doi.org/10.1111/ j.1365-2435.2008.01524.x

Cvitanovic, C., and D. R. Bellwood. 2009. Local variation in herbivore feeding activity on an inshore reef of the Great Barrier Reef. Coral Reefs 28:127-133. http://dx.doi.org/10.1007/ $\underline{\mathrm{s} 00338-008-0433-0}$

Dakos, V., M. Scheffer, E. H. van Nes, V. Brovkin, V. Petoukhov, and H. Held. 2008. Slowing down as an early warning signal for abrupt climate change. Proceedings of the National Academy of Sciences USA 105:14308-14312. http://dx.doi.org/10.1073/ pnas.0802430105
Darling, E. S., L. Alvarez-Filip, T. A. Oliver, T. R. McClanahan, and I. M. Côté. 2012. Evaluating life-history strategies of reef corals from species traits. Ecology Letters 15(12):1378-1386. http://dx.doi.org/10.1111/j.1461-0248.2012.01861.X

Darling, E. S., T. R. McClanahan, and I. M. Côté. 2013. Life histories predict coral community disassembly under multiple stressors. Global Change Biology 19(6):1930-1940. http://dx.doi. org/10.1111/gcb.12191

De'ath, G., K. E. Fabricius, H. Sweatman, and M. Puotinen. 2012. The 27-year decline of coral cover on the Great Barrier Reef and its causes. Proceedings of the National Academy of Sciences USA 109:17995-17999. http://dx.doi.org/10.1073/pnas. 1208909109

DeVantier, L. M., E. Turak, T. J. Done, and J. Davidson. 1997. The effects of cyclone Sadie on coral communities of nearshore reefs in the central Great Barrier Reef. Workshop series. Great Barrier Reef Marine Park Authority 22:65-85.

Diaz-Pulido, G. A., S. Harii, L. J. McCook, and O. HoeghGuldberg. 2010. The impact of benthic algae on the settlement of a reef-building coral. Coral Reefs 29:203-208. http://dx.doi. org/10.1007/s00338-009-0573-X

Dickens, L. C., C. H. R. Goatley, J. K. Tanner, and D. R. Bellwood. 2011. Quantifying relative diver effects in underwater visual censuses. PLoS ONE 6:e18965. http://dx.doi.org/10.1371/ journal.pone.0018965

Eckman, J. E., D. O. Duggins, and A. T. Sewel. 1989. Ecology of under story kelp environments. I. Effects of kelps on flow and particle transport near the bottom. Journal of Experimental Marine Biology and Ecology 129:173-187. http://dx.doi. org/10.1016/0022-0981(89)90055-5

Fox, R. J., and D. R. Bellwood. 2007. Quantifying herbivory across a coral reef depth gradient. Marine Ecology Progress Series 339:49-59. http://dx.doi.org/10.3354/meps339049

Fox, R. J., and D. R. Bellwood. 2008. Remote video bioassays reveal the potential feeding impact of the rabbitfish Siganus canaliculatus (f: Siganidae) on an inner-shelf reef of the Great Barrier Reef. Coral Reefs 27:605-615. http://dx.doi.org/10.1007/ $\underline{\mathrm{s} 00338-008-0359-6}$

Goatley, C. H. R., and D. R. Bellwood. 2011. The roles of dimensionality, canopies and complexity in ecosystem monitoring. PLOS ONE 6:e27307. http://dx.doi.org/10.1371/ journal.pone.0027307

Goatley, C. H. R., and D. R. Bellwood. 2012. Sediment suppresses herbivory across a coral reef depth gradient. Biology Letters 8:1016-1018. http://dx.doi.org/10.1098/rsbl.2012.0770

Goatley, C. H. R., and D. R. Bellwood. 2013. Ecological consequences of sediment on high-energy coral reefs. PLOS ONE 8:e77737. http://dx.doi.org/10.1371/journal.pone.0077737

Gordon, S. E., C. H. R. Goatley, and D. R. Bellwood. 2016. Lowquality sediments deter grazing by the parrotfish Scarus rivulatus on inner-shelf reefs. Coral Reefs 35:285-291. http://dx.doi. org/10.1007/s00338-015-1374-Z

Graham, N. A. J., D. R. Bellwood, J. E. Cinner, T. P. Hughes, A. V. Norström, and M. Nyström. 2013. Managing resilience to 
reverse phase shifts in coral reefs. Frontiers in Ecology and the Environment 11:541-548. http://dx.doi.org/10.1890/120305

Graham, N. A. J., S. K. Wilson, S. Jennings, N. V. C. Polunin, J. P. Bijoux, and J. Robinson. 2006. Dynamic fragility of oceanic coral reef ecosystems. Proceedings of the National Academy of Sciences USA 103:8425-8429. http://dx.doi.org/10.1073/pnas.0600693103

Green, A. L., and D. R. Bellwood. 2009. Monitoring functional groups of herbivorous reef fishes as indicators of coral reef resilience - a practical guide for coral reef managers in the Asia Pacific region. IUCN working group on Climate Change and Coral Reefs. International Union for Conservation of Nature, Gland, Switzerland.

Guttal, V., and C. Jayaprakash. 2008. Changing skewness: an early warning signal of regime shifts in ecosystems. Ecology Letters 11:450-460. http://dx.doi.org/10.1111/j.1461-0248.2008.01160.x

Hay, M. E. 1981. The functional morphology of turf-forming seaweeds: persistence in stressful marine habitats. Ecology 62:739-750.

Hixon, M. A., and W. N. Brostoff. 1996. Succession and herbivory: effects of differential fish grazing on Hawaiian coral-reef algae. Ecological Monographs 66:67-90.

Hoey, A. S., and D. R. Bellwood. 2010. Cross-shelf variation in browsing intensity on the Great Barrier Reef. Coral Reefs 29:499-508. http://dx.doi.org/10.1007/s00338-010-0605-6

Hoey, A. S., and D. R. Bellwood. 2011. Suppression of herbivory by macroalgal density: a critical feedback on coral reefs? Ecology Letters 14:267-273. http://dx.doi.org/10.1111/j.1461-0248.2010.01581. $\underline{\mathrm{x}}$

Hughes, T. P., C. Linares, V. Dakos, I. A. van de Leemput, and E. H. van Nes. 2013. Living dangerously on borrowed time during slow, unrecognized regime shifts. Trends in Ecology \& Evolution 28:149-155. http://dx.doi.org/10.1016/j.tree.2012.08.022

Hughes, T. P., M. J. Rodrigues, D. R. Bellwood, D. Ceccarelli, O. Hoegh-Guldberg, L. McCook, N. Moltschaniwskyj, M. S. Pratchett, R. S. Steneck, and B. Willis. 2007. Phase shifts, herbivory, and the resilience of coral reefs to climate change. Current Biology 17:360-365. http://dx.doi.org/10.1016/j.cub.2006.12.049

Kramer, M. J., D. R. Bellwood, and O. Bellwood. 2012. Cryptofauna of the epilithic algal matrix on an inshore coral reef, Great Barrier Reef. Coral Reefs 31:1007-1015. http://dx.doi. org/10.1007/s00338-012-0924-X

Kramer, M. J., O. Bellwood, and D. R. Bellwood. 2013. The trophic importance of algal turfs for coral reef fishes: the crustacean link. Coral Reefs 32:575-583. http://dx.doi. org/10.1007/s00338-013-1009-1

Kroon, F. J., P. M. Kuhnert, B. L. Henderson, S. N. Wilkinson, A. Kinsey-Henderson, B. Abbott, J. E. Brodie, and R. D. R. Turner. 2012. River loads of suspended solids, nitrogen, phosphorus and herbicides delivered to the Great Barrier Reef lagoon. Marine Pollution Bulletin 65:167-181. http://dx.doi. org/10.1016/j.marpolbul.2011.10.018

Lefèvre, C. D., and D. R. Bellwood. 2011. Temporal variation in coral reef ecosystem processes: herbivory of macroalgae by fishes. Marine Ecology Progress Series 422:239-251. http://dx.doi. org/10.3354/meps08916
Loffler, Z., D. R. Bellwood, and A. S. Hoey. 2015a. Amonghabitat algal selectivity by browsing herbivores on an inshore coral reef. Coral Reefs 34:597-605. http://dx.doi.org/10.1007/ s00338-015-1265-3

Loffler, Z., D. R. Bellwood, and A. S. Hoey. 2015b. Associations among coral reef macroalgae influence feeding by herbivorous fishes. Coral Reefs 34:51-55. http://dx.doi.org/10.1007/s00338-014-1236-0

Lokrantz, J., M. Nyström, M. Thyresson, and C. Johansson. 2008. The non-linear relationship between body size and function in parrotfishes. Coral Reefs 27:967-974. http://dx.doi.org/10.1007/ s00338-008-0394-3

Mantyka, C. S., and D. R. Bellwood. 2007. Direct evaluation of macroalgal removal by herbivorous coral reef fishes. Coral Reefs 26:435-442. http://dx.doi.org/10.1007/s00338-007-0214-1

McClanahan, T. R., N. A. J. Graham, M. A. MacNeil, N. A. Muthiga, J. E. Cinner, J. H. Bruggemann, and S. K. Wilson. 2011. Critical thresholds and tangible targets for ecosystem-based management of coral reef fisheries. Proceedings of the National Academy of Sciences USA 108:17230-17233. http://dx.doi. org/10.1073/pnas. 1106861108

Mouillot, D., D. R. Bellwood, C. Baraloto, J. Chave, R. Galzin, M. Harmelin-Vivien, M. Kulbicki, S. Lavergne, S. Lavorel, N. Mouquet, C. E. T. Paine, J. Renaud, and W. Thuiller. 2013. Rare species support vulnerable functions in high-diversity ecosystems. PLoS Biology 11:e1001569. http://dx.doi.org/10.1371/journal. pbio. 1001569

Mouillot, D., S. Villeger, V. Parravicini, M. Kulbicki, J. E. AriasGonzález, M. Bender, P. Chabanet, S. R. Floeter, A. Friedlander, L. Vigliola, and D. R. Bellwood. 2014. Functional overredundancy and high functional vulnerability in global fish faunas on tropical reefs. Proceedings of the National Academy of Sciences USA 111:13757-13762. http://dx.doi.org/10.1073/ pnas. 1317625111

Nash, K. L., N. A. J. Graham, S. Jennings, S. K. Wilson, and D. R. Bellwood. 2015. Herbivore cross-scale redundancy supports response diversity and promotes coral reef resilience. Journal of Applied Ecology http://dx.doi.org/10.1111/1365-2664.12430

Norström, A. V., M. Nyström, J. Lokrantz, and C. Folke. 2009. Alternative states on coral reefs: beyond coral-macroalgal phase shifts. Marine Ecology Progress Series 376:295-306. http://dx.doi. org/10.3354/meps07815

Nyström, M. 2006. Redundancy and response diversity of functional groups: implications for the resilience of coral reefs. AMBIO: A Journal of the Human Environment 35:30-35. http:// dx.doi.org/10.1579/0044-7447-35.1.30

Nyström, M., N. A. J. Graham, J. Lokrantz, and A. V. Norström. 2008. Capturing the cornerstones of coral reef resilience: linking theory to practice. Coral Reefs 27:795-809. http://dx.doi. org/10.1007/s00338-008-0426-Z

Perry, C. T., S. G. Smithers, P. S. Kench, and B. Pears. 2014. Impacts of Cyclone Yasi on nearshore, terrigenous sedimentdominated reefs of the central Great Barrier Reef, Australia. Geomorphology 222:92-105. http://dx.doi.org/10.1016/j. geomorph.2014.03.012 
Purcell, S. W. 1996. A direct method for assessing sediment load in epilithic algal communities. Coral Reefs 15:211-213. http://dx. doi.org/10.1007/bf01787453

Scheffer, M., J. Bascompte, W. A. Brock, V. Brovkin, S. R. Carpenter, V. Dakos, H. Held, E. H. van Nes, M. Rietkerk, and G. Sugihara. 2009. Early-warning signals for critical transitions. Nature 461:53-59. http://dx.doi.org/10.1038/nature08227

Scheffer, M., S. Carpenter, J. A. Foley, C. Folke, and B. Walker. 2001. Catastrophic shifts in ecosystems. Nature 413:591-596. http://dx.doi.org/10.1038/35098000

Streit, R. P., A. S. Hoey, and D. R. Bellwood. 2015. Feeding characteristics reveal functional distinctions among browsing herbivorous fishes on coral reefs. Coral Reefs 34:1037-1047. http:// dx.doi.org/10.1007/s00338-015-1322-y

Trapon, M. L., M. S. Pratchett, A. S. Hoey, and A. H. Baird. 2013. Influence of fish grazing and sedimentation on the early postsettlement survival of the tabular coral Acropora cytherea. Coral Reefs 32:1051-1059. http://dx.doi.org/10.1007/s00338-013-1059-4

Umar, M. J., L. J. McCook, and I. R. Price. 1998. Effects of sediment deposition on the seaweed Sargassum on a fringing coral reef. Coral Reefs 17:169-177. http://dx.doi.org/10.1007/ $\underline{\mathrm{s} 003380050111}$

van Nes, E. H., and M. Scheffer. 2005. A strategy to improve the contribution of complex simulation models to ecological theory. Ecological Modelling 185:153-164. http://dx.doi.org/10.1016/j. ecolmodel.2004.12.001

Vergés, A., S. Bennett, and D. R. Bellwood. 2012. Diversity among macroalgae-consuming fishes on coral reefs: a transcontinental comparison. PLoS ONE 7:e45543. http://dx.doi.org/10.1371/ journal.pone.0045543

Villéger, S., P. M. Novack-Gottshall, and D. Mouillot. 2011. The multidimensionality of the niche reveals functional diversity changes in benthic marine biotas across geological time. Ecology Letters 14:561-568. http://dx.doi.org/10.1111/j.1461-0248.2011.01618. $\underline{\mathrm{x}}$

Vroom, P. S. 2011. "Coral dominance": a dangerous ecosystem misnomer? Journal of Marine Biology 2011:164127. http://dx.doi. org/10.1155/2011/164127

Walther, B. D., M. J. Kingsford, and M. T. McCulloch. 2013. Environmental records from Great Barrier Reef corals: inshore versus offshore drivers. PLoS ONE 8:e77091. http://dx.doi. org/10.1371/journal.pone.0077091

Welsh, J. Q., and D. R. Bellwood. 2012. Spatial ecology of the steephead parrotfish (Chlorurus microrhinos): an evaluation using acoustic telemetry. Coral Reefs 31(1):55-65. http://dx.doi. org/10.1007/s00338-011-0813-8

Wilson, S. K., D. R. Bellwood, J. H. Choat, and M. J. Furnas. 2003. Detritus in the epilithic algal matrix and its use by coral reef fishes. Oceanography and Marine Biology 41:279-309. 


\section{Appendix 1}
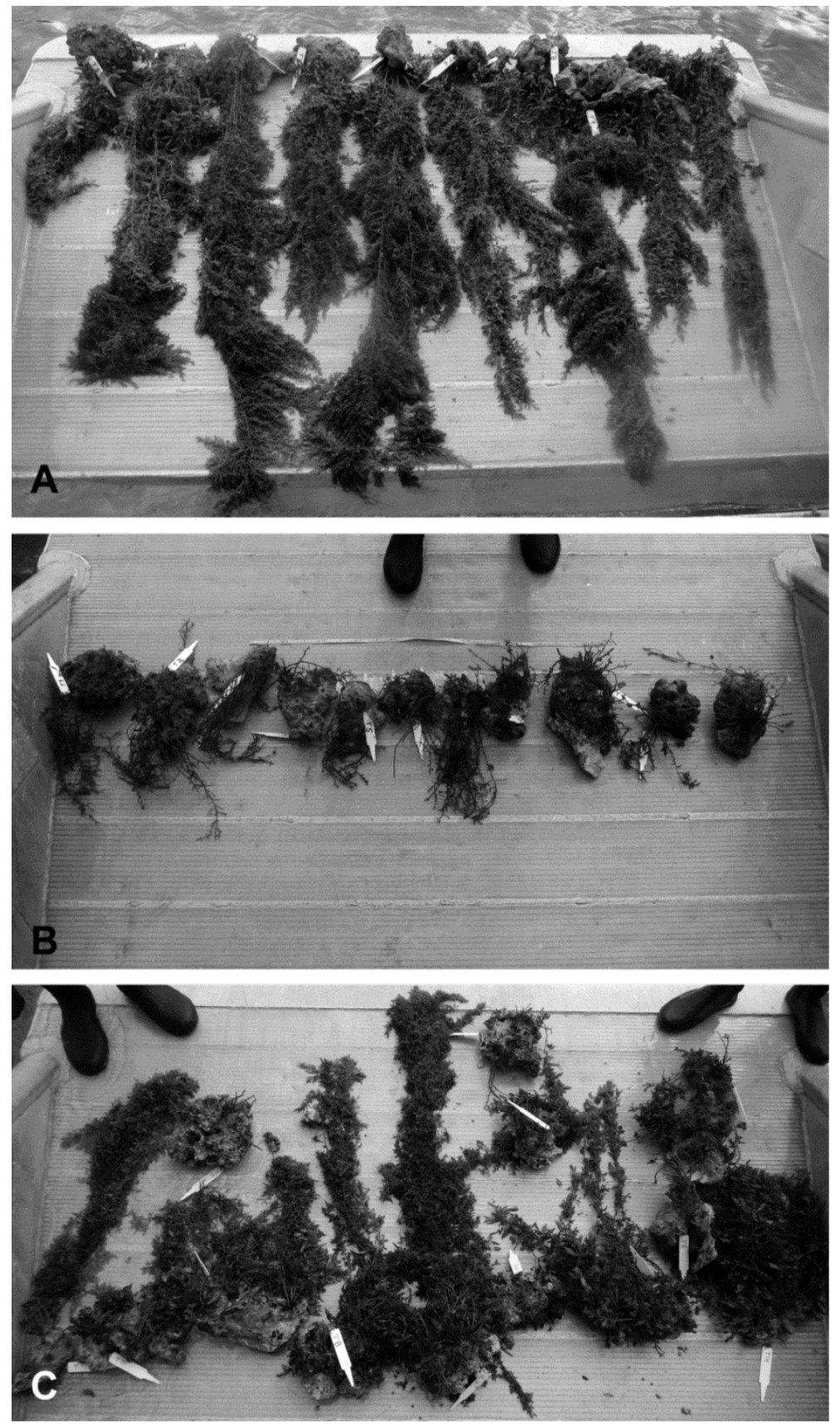

Figure A1.1. A Standard macroalgal bioassays upon deployment. B Macroalgal bioassays collected 24 hours later for every deployment 1996-2010 (and 2011-2013 second annual deployments). This extent of removal was considered 'largely removed'. C Macroalgal bioassays collected 24 hours after first annual deployment 2011-2013. Barring the three rocks to the top of the image, this degree of removal would be considered 'largely intact'. 
Table A1.1. Functional groups and species assigned to each, observed in Pioneer Bay, Orpheus Island. Facultative herbivores include species that often feed on algae but may have a large dietary component of invertebrates or other prey. These include the primarily invertivorous non-farming

\begin{tabular}{|c|c|}
\hline Functional group & Species observed \\
\hline Facultative herbivores & $\begin{array}{l}\text { Pomacentrus adelus } \\
\text { Pce. bankanensis } \\
\text { Pce. chrysurus } \\
\text { Pce. wardi } \\
\text { Abudefduf bengalensis } \\
\text { Ab. sexfasciatus } \\
\text { Ab. vaigiensis } \\
\text { Ab. whitleyi } \\
\text { Pomacanthus xanthometopon } \\
\text { Pca. sexstriatus }\end{array}$ \\
\hline Farming damselfishes & $\begin{array}{l}\text { Stegastes apicalis } \\
\text { St. nigricans } \\
\text { Dischistodus melanotus } \\
\text { D. prosopotaenia } \\
\text { Hemiglyphidodon plagiometopon } \\
\text { Neoglyphidodon melas } \\
\text { N. nigroris }\end{array}$ \\
\hline Scrapers & $\begin{array}{l}\text { Hipposcarus longiceps } \\
\text { Scarus altipinnis } \\
\text { Sc. flavipectoralis } \\
\text { Sc. frenatus } \\
\text { Sc. ghobban } \\
\text { Sc. niger } \\
\text { Sc. rivulatus } \\
\text { Sc. schlegeli } \\
\text { Sc. spp. }\end{array}$ \\
\hline Excavators & $\begin{array}{l}\text { Chlorurus spilurus } \\
\text { Ch. microrhinos }\end{array}$ \\
\hline Browsers & $\begin{array}{l}\text { Naso unicornis } \\
\text { Kyphosus cinarescens } \\
\text { Platax pinnatus } \\
\text { Pl. teira }\end{array}$ \\
\hline Grazing surgeonfishes & Acanthurus spp. \\
\hline Grazing rabbitfishes & $\begin{array}{l}\text { Siganus corallinus } \\
\text { Sig. doliatus } \\
\text { Sig. lineatus } \\
\text { Sig. puellus } \\
\text { Sig. punctatus } \\
\text { Sig. vulpinus } \\
\end{array}$ \\
\hline
\end{tabular}

damselfishes (Pomacentridae) and angelfishes (Pomacanthidae). Farming damselfishes (Pomacentridae) are a specialist group which defend territories of algal turfs from other herbivorous fishes; their diet is likely to include a portion of the algae they farm however the primary target is infauna and detritus accumulated within (Wilson and Bellwood 1997, Ceccarelli et al. 2005). Scraping and excavating are the two primary modes of feeding in the parrotfishes (Labridae, Tribe: Scarini) defined by (Bellwood and Choat 1990, Bonaldo and Bellwood 2009). The former removes EAMs leaving the carbonate reef matrix largely intact while the latter also removes portions of the carbonate reef matrix while feeding. Browsers prey upon the thalli and fronds of macroalgae and may be responsible for reversing shifts to macroalgal dominance. Grazing surgeonfishes feed upon all components of EAMs while leaving algal holdfasts and the reef matrix essentially untouched (Purcell and Bellwood 1993). Grazing rabbitfishes target similar prey to grazing surgeonfishes, however they often feed on material from crevices on the reef (Brandl et al. 2014, Brandl and Bellwood 2015). 


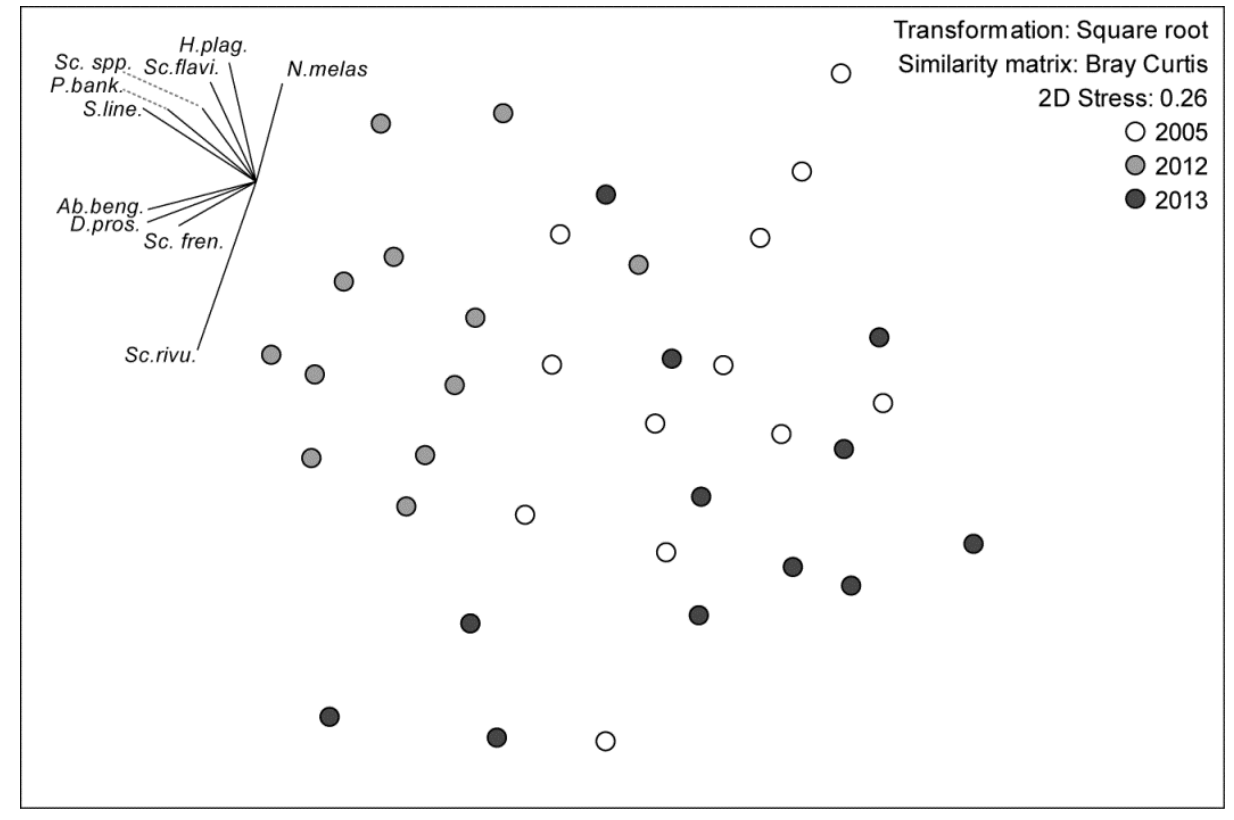

Figure A1.2. Taxonomic MDS on biomass of species; vectors calculated using multiple partial correlations in PRIMER 6.0 PERMANOVA +. 1 way ANOSIM with sites pooled: Global R=0.39. No groupings are apparent.

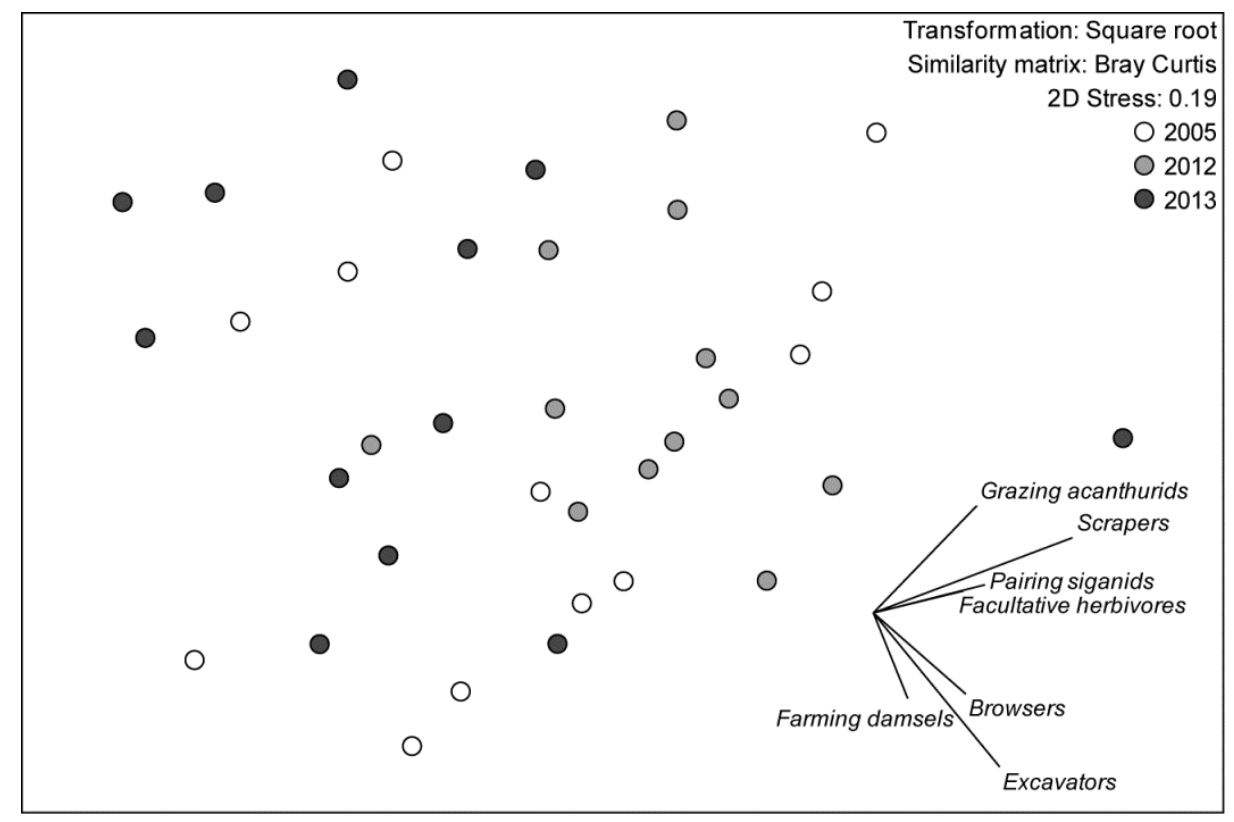

Figure A1.3. Functional group MDS of biomass data of seven functional groups of herbivorous fishes (see Table S1); vectors calculated using multiple partial correlations in PRIMER 6.0 PERMANOVA+. 1 way ANOSIM with sites pooled: Global $\mathrm{R}=0.2$. No groupings are apparent. 
Table A1.2. The taxonomic composition of the herbivorous fish assemblage at each sampling period. Numbers represent the mean percentage of biomass of the herbivorous fish assemblage made up by each family. Numbers in parentheses are standard errors $(n=12$ replicate censuses per period [sites pooled]).

\begin{tabular}{lcrcc}
\hline Family & \multicolumn{2}{c}{2005} & 2012 & 2013 \\
\hline Acanthuridae & $5.06(2.00)$ & $9.86(2.86)$ & $3.47(1.79)$ \\
Ephippidae & - & - & $2.15(1.80)$ & - \\
Kyphosidae & - & - & $2.11(1.65)$ & - \\
Labridae & $67.66(6.07)$ & $55.62(4.26)$ & $71.10(4.95)$ \\
Pomacanthidae & - & - & $4.73(2.00)$ & $8.32(3.07)$ \\
Pomacentridae & $5.10(3.32)$ & $3.61(0.75)$ & $4.46(1.72)$ \\
Siganidae & $22.18(4.55)$ & $21.91(3.40)$ & $12.65(2.71)$ \\
\hline
\end{tabular}

Table A1.3. Two-way ANOVA of mass standardised bite data of grazing herbivores on $1 \mathrm{~m}^{2}$ plots of EAM on the reef crest at Orpheus Island (sites pooled as no significant difference was found, data square-root transformed to meet assumptions of the test).

\begin{tabular}{lccccc}
\hline & SS & DF & MS & F & p \\
\hline Year & 74.42 & 2 & 37.21 & 32.15 & $<0.0001$ \\
Taxon & 37.41 & 1 & 37.41 & 32.32 & $<0.0001$ \\
Year $\times$ Taxon & 20.63 & 2 & 10.31 & 8.910 & $<0.001$ \\
Residual & 77.55 & 67 & 1.158 & & \\
\hline
\end{tabular}

Table A1.4. Two-way ANOVA of turf length bioassay data, comparing lengths of algal turfs on EAM covered rocks moved from the reef flat to the crest (treatment) with controls moved and replaced on the flat. pooling site where it was found to have no effect (sites pooled as no significant difference was found, data $\log 10(\mathrm{n}+1)$ transformed to meet assumptions of the test).

\begin{tabular}{lccccc}
\hline & SS & DF & MS & F & p \\
\hline Year & 0.955 & 2 & 0.477 & 52.38 & $<0.0001$ \\
Treatment & 0.110 & 1 & 0.110 & 12.09 & $<0.001$ \\
Year $\times$ Treatment & 0.392 & 2 & 0.196 & 21.49 & $<0.0001$ \\
Residual & 0.674 & 74 & 0.009 & & \\
\hline
\end{tabular}


Table A1.5. Repeated measure ANOVA of sediment load over time and material (particulate vs. sediment).

\begin{tabular}{lccccc}
\hline & SS & DF & MS & F & p \\
\hline Year $\times$ Material & 0.639 & 1 & 0.639 & 4.546 & 0.047 \\
Material & 32.59 & 1 & 32.59 & 232.0 & $<0.0001$ \\
Year & 5092 & 1 & 5092 & 34.62 & $<0.0001$ \\
Subjects (matching) & 2648 & 18 & 147.1 & 1047 & $<0.0001$ \\
Residual & 2.529 & 18 & 0.141 & & \\
\hline
\end{tabular}

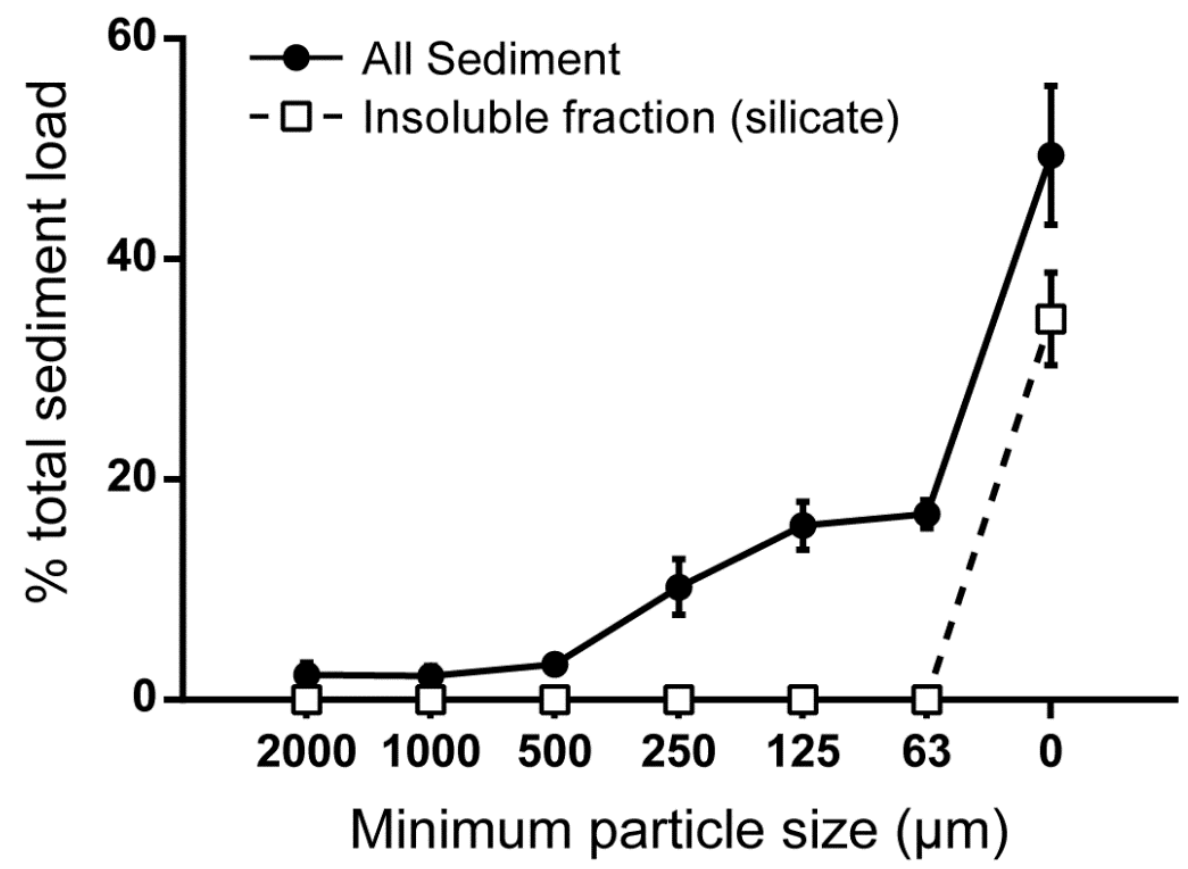

Figure A1.4. Grain size distribution of all sediment (circles) and insoluble fraction (siliceous material; squares) of 10 replicate benthic sediment samples taken from Pioneer Bay reef crest. On average $34.6 \pm 4.2 \%$ (mean \pm standard error) of each sediment sample was siliceous material, all of which was in the $<63 \mu \mathrm{m}$ grain size category. On average $70.9 \pm 2.2 \%$ of all sediment in this grain size class was siliceous material. 


\section{LITERATURE CITED}

Bellwood, D. R., and J. H. Choat. 1990. A functional analysis of grazing in parrotfishes (family Scaridae): the ecological implications. Environmental Biology of Fishes 28:189-214.

Bonaldo, R. M., and D. R. Bellwood. 2009. Dynamics of parrotfish grazing scars. Marine Biology 156(4):771-777.

Brandl, S. J., and D. R. Bellwood. 2015. Coordinated vigilance provides evidence for direct reciprocity in coral reef fishes. Scientific Reports 5:14556.

Brandl, S. J., A. S. Hoey, and D. R. Bellwood. 2014. Micro-topography mediates interactions between corals, algae, and herbivorous fishes on coral reefs. Coral Reefs 33:421-430.

Ceccarelli, D. M., G. P. Jones, and L. J. McCook. 2005. Foragers versus farmers: Contrasting effects of two behavioural groups of herbivores on coral reefs. Oecologia 145(3):445-453.

Purcell, S. W., and D. R. Bellwood. 1993. A functional analysis of food procurement in two surgeonfish species, Acanthurus nigrofuscus and Ctenochaetus striatus (Acanthuridae). Environmental Biology of Fishes 37(2):139-159.

Wilson, S. K., and D. R. Bellwood. 1997. Cryptic dietary components of territorial damselfishes (Pomacentridae, Labroidei). Marine Ecology Progress Series 153:299-310. 